\title{
THE EFFECT OF AIR QUALITY ON THE INCIDENCE OF ACUTE RESPIRATORY INFECTION (ARI) IN PONTIANAK CITY
}

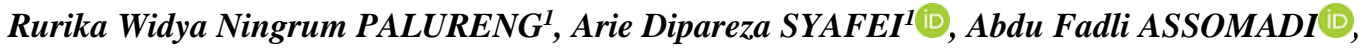 \\ Rachmad BOEDISANTOSO, Joni HERMANA, Wayan SUPARTA2
}

DOI: 10.21163/GT_2020.152.03

\begin{abstract}
:
The Regional Health Office of Pontianak City stated that in 2017, acute respiratory infection (ARI) was the most common disease in the community with 83,128 cases, highest incindence in West Kalimantan. Air is the transmission medium of ARI. The incidence of ARI increases with population growth which can be a source of air pollution due to the many activities. This study aimed to determine the effect of air quality and the effect of the season on the incidence of ARI disease in Pontianak and policies that can be established by relevant government agencies to deal with ARI. The research used secondary data, consisted of air quality and ARI incidence data. The determination was analyzed using multiple linear regression statistical methods using the RStudio software application. The results found that air quality affected $46.71 \%$ of the ARI incidence in Pontianak. Influential pollutants are $\mathrm{NO}_{2}, \mathrm{SO}_{2}$, and $\mathrm{CO}_{2}$. Analysis of the effect of the season showed that the air quality during the rainy season affected $65.76 \%$, while in the dry season affected $22.67 \%$ of the ARI incidence in Pontianak. So to reduce the incidence of ARI in Pontianak, the action that we can take is by improving the air quality.
\end{abstract}

Key-words: Acute Respiratory Infection (ARI), Air quality, Multiple linear regression, RStudio.

\section{INTRODUCTION}

The World Health Organization (WHO) has reported that as many as 1.9 million children aged less than five die from acute respiratory infection (ARI) each year. Around $70 \%$ of ARIs occur in Africa and Southeast Asia. Based on epidemiological studies, the incidence of ARI in developing countries is estimated to reach $25 \%$ in children under the age of five years.

Indonesia is ranked as the country with the fifth-highest ARI incidence in the world (Anggraeni, 2017). ARI is among the top 10 diseases in hospitals. A mortality survey in 2013 placed ARI as the largest cause of mortality among children under five in Indonesia, causing $32.10 \%$ of deaths. Based on data from the Pontianak City Health Office (2018), the most common illness among people living in Pontianak City in 2017 was ARI. The data is based on reports from all community health centers in Pontianak. There were 83,128 cases of ARI in that year. Based on the RISKESDAS by the Indonesian Ministry of Health (2018) it was stated that Pontianak is the city with the highest ARI prevalence in West Kalimantan Province.

ARI attacks the body through the upper and lower respiratory tract, from the nose to the alveoli, including the adnexa, the sinus of the middle ear cavity, and the pleura. This infection is acute, lasting up to 14 days. ARI is usually caused by a virus or bacterium (Gagarani, 2015). Dinayah (2014) stated that the health status of a person is influenced by environmental factors, health behavior, available health services, and genetic factors. Of these, environmental factors have a greater influence on ARI. Poor environmental health and extreme climatic conditions can contribute greatly to health status (Haidu, 2009). Environmental factors also include air pollution (Hysenaj, 2019). According to Anggraeni (2017), air is a transmission medium for the cause of ARI, whether it is dust, bacteria, or viruses. Air is therefore a major environmental component in the spread of ARI.

Air quality is a problem closely related to the urban situation in Indonesia. Pontianak is the capital city of West Kalimantan Province that has a population of 637,723, with an annual growth rate of

\footnotetext{
${ }^{1}$ Institut Teknologi Sepuluh Nopember, Department of Environmental Engineering, 60111, Surabaya, Indonesia, dipareza@enviro.its.ac.id.

${ }^{2}$ Universitas Pembangunan Jaya, Department of Informatics, South Tangerang City, Banten 15413, Indonesia, Corresponding author: wayan.suparta@upj.ac.id
} 
1.84\% (BPS Pontianak City, 2019). According to Aprianto et al. (2018), the presence of a large number of residents in a city can be a source of air pollution because of the many activities that occur, including industrial activities, offices, land fires, and transportation. Based on the Indonesian National Board for Disaster Management (2018), forest fires occur in Pontianak City every year and in 2018 there are 21 incidents with the number of transportation which is grow every year. Therefore, this study was conducted with the aim of determining and identifying the effect of air quality ARI incidence in Pontianak, determining and identifying the effect of seasons on incidence, and determining policies that can be established by the relevant government agencies to deal with ARI.

\section{METHODOLOGY}

\subsection{Study Area}

This study used a research design based on ecological time trend study. Ecological study according to time is a research study design used to determine the relationship between the frequency of illness or death due to a type of disease in society over time (Adriyani, 2012). The research was located in Pontianak City. Pontianak City is the capital of West Kalimantan Province. The total area of Pontianak City is $107.82 \mathrm{~km}^{2}$. Pontianak City is situated on the equator line, with latitude coordinates of $00^{\circ} 02^{\prime} 24^{\prime \prime} \mathrm{N}-00^{0} 5^{\prime} 37^{\prime \prime} \mathrm{S}$ and longitude coordinates of $109^{0} 16^{\prime} 25^{\prime \prime} \mathrm{E}-109^{0} 23^{\prime} 04^{\prime \prime} \mathrm{E}$. Pontianak City is divided into six subdistricts: Pontianak Kota, Pontianak Barat, Pontianak Selatan, Pontianak Tenggara, Pontianak Timur, and Pontianak Utara, with a total of 29 urban villages (BPS Kota Pontianak, 2018). As a fulfillment of its health facilities aspect, Pontianak City is equipped with 23 community health centers.

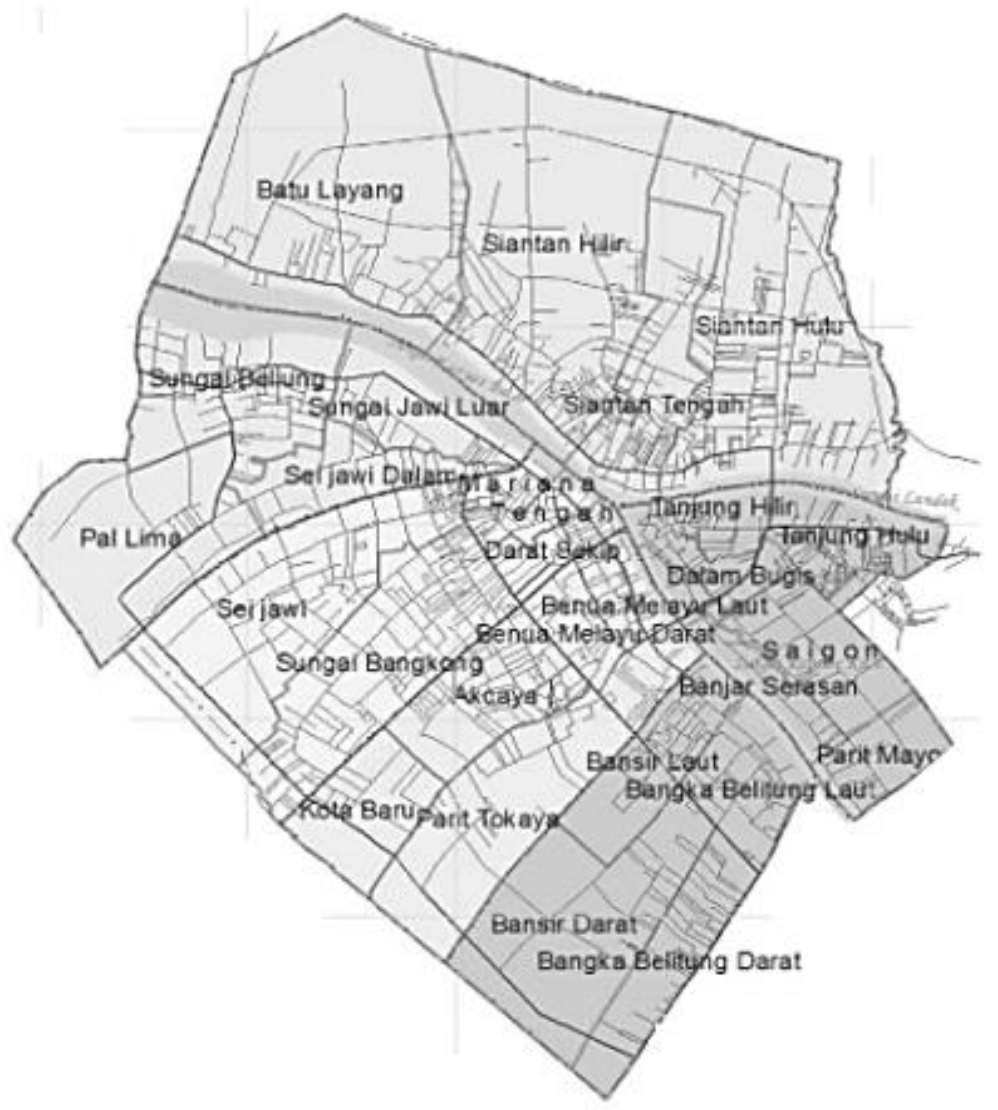

Fig. 1. Map of Pontianak City (Source: BPS Kota Pontianak, 2018). 
As an effort to manage air quality and control air pollution, Pontianak City has an air quality monitoring device commonly called the Air Quality Management System (AQMS). This tool is located in the Pontianak Tenggara Subdistrict Office, in accordance with the criteria for the placement of ambient air quality monitoring instruments in the State Minister of Environment Regulation No. 12 of 2010 concerning the Implementation of Air Pollution Control in the Region. The sampling inlet is \pm 6 meters from the ground and free from barriers, with an open angle of $120^{\circ}$.

The AQMS tool detects Pontianak City air quality concentrations in the form of sulfur dioxide $\left(\mathrm{SO}_{2}\right)$, nitrogen dioxide $\left(\mathrm{NO}_{2}\right)$, carbon monoxide $(\mathrm{CO})$, ozone $\left(\mathrm{O}_{3}\right)$, and particulate matter $\left(\mathrm{PM}_{10}\right)$ concentrations. The raw data is sent every 30 minutes to the national Ministry of Environment and Forestry server, which displays the Air Pollution Index (API) figures daily at $3 \mathrm{pm}$. This can be accessed by the entire community so that the public can obtain information about air quality status.

\subsection{Statistical Analysis}

This research used secondary data to identify the effect of air quality in the form of $\mathrm{SO}_{2}, \mathrm{NO}_{2}$, $\mathrm{CO}, \mathrm{O}_{3}$, and $\mathrm{PM}_{10}$ concentrations on ARI incidence from 2012-2018 in Pontianak City, based on monthly report data. Respiratory disease data were obtained from the Pontianak City Health Office and air quality data were obtained from the Pontianak City Environment Office.

The analysis used univariate and bivariate analysis. Univariate analysis was performed to determine the frequency distribution, minimum value, maximum value, and average value of air quality variables. The results are presented as a monthly trend graph. Bivariate analysis was performed to identify the relationship between air quality and the ARI incidence in Pontianak, conducted with multiple linear regression methods using the RStudio application. The multiple linear regression models is used to examine the relationship or effect of two or more independent variables on the dependent variable. The general form of multiple linear regression models is as follows (Kutner, 2004):

$$
Y_{i}=\beta_{0}+\beta_{1} X_{i 1}+\beta_{2} X_{i 2}+\cdots+\beta_{n} X_{i n}+\varepsilon_{i}
$$

where

$Y_{i}$

$\beta_{0}, \beta_{1}, \ldots, \beta_{n}$

$X_{i 1}, X_{i 2}, \ldots, X_{i n}$

$\varepsilon_{i}$

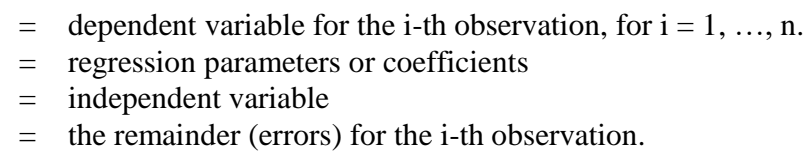

Known variables in this study are as follows:

- Dependent variable $\left(Y_{i}\right)$

The dependent variable in this study is ARI, which consists of pneumonia, severe pneumonia, or not pneumonia.

- Independent variable $\left(X_{i n}\right)$

The independent variables in this study include air quality data and meteorological data. The air quality data includes the concentration of air pollutant parameters at the API station, namely $\mathrm{CO}$ $\left(\mu \mathrm{g} / \mathrm{m}^{3}\right), \mathrm{O}_{3}\left(\mu \mathrm{g} / \mathrm{m}^{3}\right), \mathrm{NO}_{2}\left(\mu \mathrm{g} / \mathrm{m}^{3}\right), \mathrm{SO}_{2}\left(\mu \mathrm{g} / \mathrm{m}^{3}\right)$, and $\mathrm{PM}_{10}\left(\mu \mathrm{g} / \mathrm{m}^{3}\right)$.

\section{RESULTS AND DISCUSSIONS}

\subsection{Univariate Analysis of Each Concentration}

Univariate analysis results provide an overview of each research variable in the form of air quality concentration, namely $\mathrm{SO}_{2}, \mathrm{NO}_{2}, \mathrm{CO}, \mathrm{O}_{3}$, and $\mathrm{PM}_{10}$. 


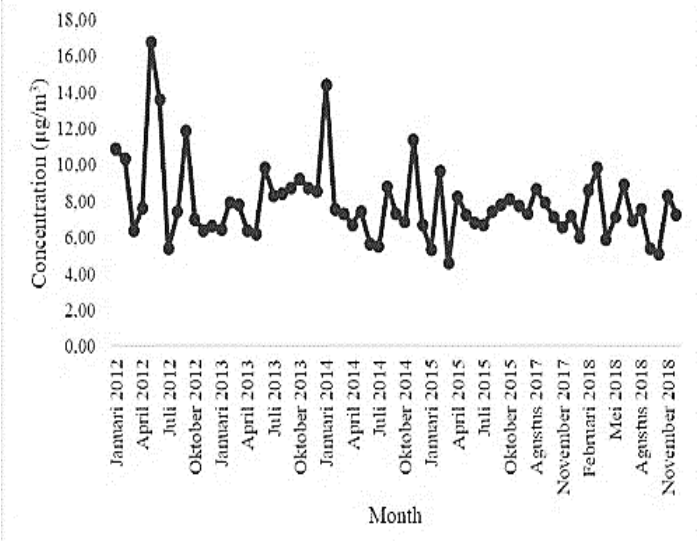

Fig. 2. $\mathrm{NO}_{2}$ air quality in Pontianak City, 2012-2018.

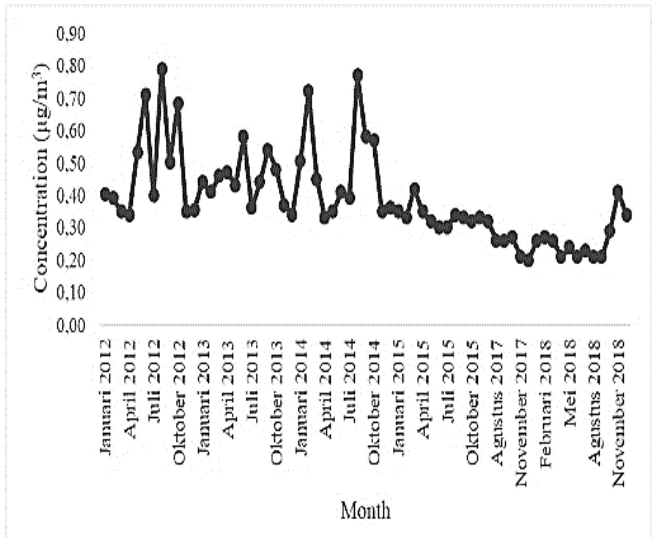

Fig. 3. CO air quality in Pontianak City, 2012-2018.

The results of the analysis based on the Fig. 2 showed an average value of $\mathrm{NO}_{2}$ of $7.90 \mu \mathrm{g} / \mathrm{m}^{3}$ with a standard deviation of 7.90. The lowest $\mathrm{NO}_{2}$ concentration was $4.57 \mu \mathrm{g} / \mathrm{m}^{3}$ while the highest was $16.74 \mu \mathrm{g} / \mathrm{m}^{3}$. The average value of $\mathrm{NO}_{2}$ when converted to API figures became TD (not specified), which based on the Decree of the Minister of Environment No. KEP-45/MENLH 10/1997 is in the 'good' category.

The results of the analysis based on the Fig.3 showed an average value of $\mathrm{CO}$ of $0.39 \mathrm{mg} / \mathrm{m}^{3}$ with a standard deviation of 0.14 . The lowest $\mathrm{NO}_{2}$ concentration was $0.20 \mathrm{mg} / \mathrm{m}^{3}$ while the highest was $0.79 \mathrm{mg} / \mathrm{m}^{3}$. The average value of $\mathrm{NO}_{2}$ when converted to API figures became 3.9 , which based on the Decree of the Minister of Environment No. KEP-45/MENLH 10/1997 is in the 'good' category.

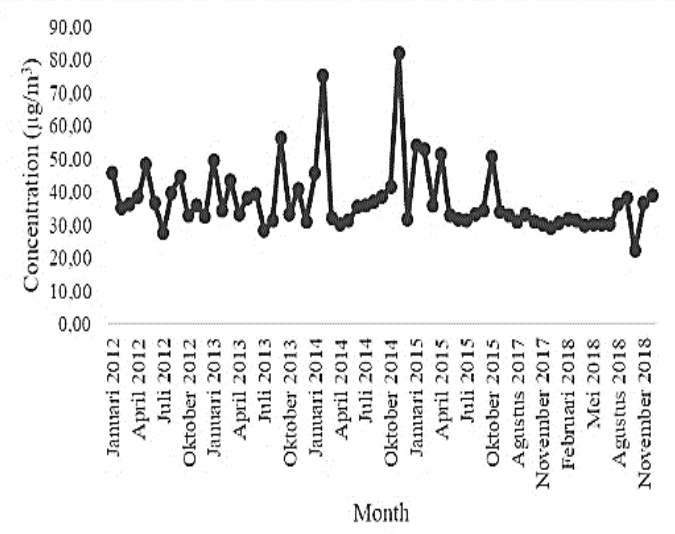

Fig. 4. $\mathrm{O}_{3}$ air quality in Pontianak City, 2012-2018.

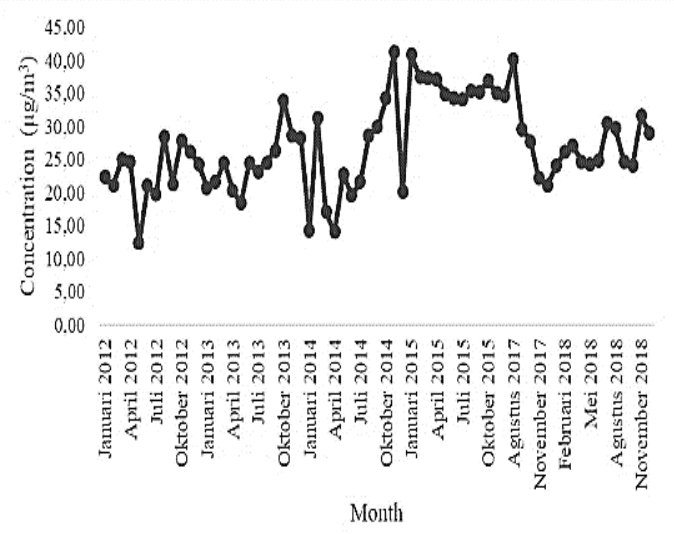

Fig. 5. $\mathrm{SO}_{2}$ air quality in Pontianak City, 2012-2018.

The results of the analysis based on the Fig.4 showed an average value of $\mathrm{O}_{3}$ of $37.61 \mu \mathrm{g} / \mathrm{m}^{3}$ with a standard deviation of 7.90. The lowest $\mathrm{O}_{3}$ concentration was $22.28 \mu \mathrm{g} / \mathrm{m}^{3}$ while the highest was $82.08 \mu \mathrm{g} / \mathrm{m}^{3}$. The average value of $\mathrm{O}_{3}$ when converted to API figures became 15.67, which based on the Decree of the Minister of Environment No. KEP-45/MENLH 10/1997 is in the 'good' category.

The results of the analysis based on the Fig.5 showed an average value of $\mathrm{SO}_{2}$ of $27.04 \mu \mathrm{g} / \mathrm{m}^{3}$ with a standard deviation of 7.90. The lowest $\mathrm{SO}_{2}$ concentration was $12.32 \mu \mathrm{g} / \mathrm{m}^{3}$ while the highest was $41.22 \mu \mathrm{g} / \mathrm{m}^{3}$. 
The average value of $\mathrm{SO}_{2}$ when converted to API figures became 16.9, which based on the Decree of the Minister of Environment No. KEP-45/MENLH 10/1997 is in the 'good' category. The results of the analysis based on the Fig.6 showed an average value of $\mathrm{PM}_{10}$ of $41.26 \mu \mathrm{g} / \mathrm{m}^{3}$ with a standard deviation of 7.90. The lowest $\mathrm{PM}_{10}$ concentration was $12.25 \mu \mathrm{g} / \mathrm{m}^{3}$ while the highest was 146.54 $\mu \mathrm{g} / \mathrm{m}^{3}$. The average value of $\mathrm{PM}_{10}$ when converted to API figures became 41.26 , which based on the Decree of the Minister of Environment No. KEP-45/MENLH 10/1997 is in the 'good' category but approaching 'moderate'.

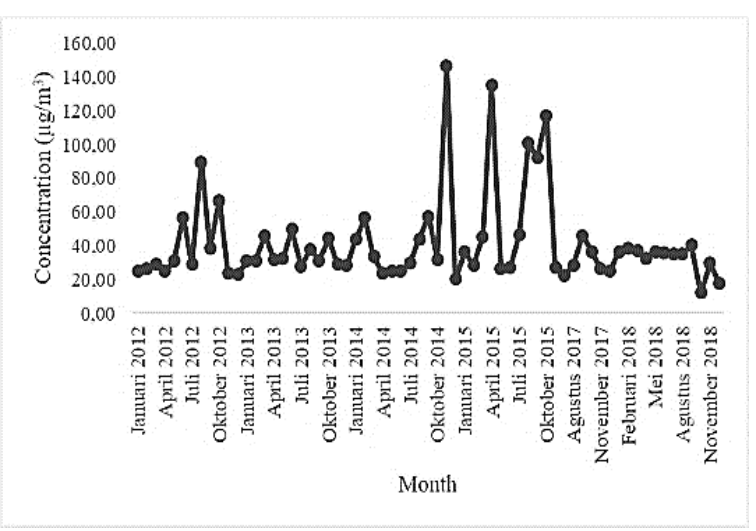

Fig. 6. $\mathrm{PM}_{10}$ air quality in Pontianak City, 2012-2018.

\subsection{Bivariate Analysis and Effect of Air Quality on ARI Incidence in Pontianak City}

Before analyzing the effect of air quality on ARI incidence in Pontianak using multiple linear regression models, a correlation analysis test was performed as shown in Table $\mathbf{1}$ to get correlation between two variables, independent variable and the dependent variable. If the p-value is smaller than the significance value $(\alpha=0.05)$, so there's a correlation between the two variables.

Based on Table 1, all the independent variables have a correlation with the dependent variable. Then the estimation results of multiple linear regression models regarding the impact of air quality $\mathrm{NO}_{2}, \mathrm{CO}, \mathrm{O}_{3}, \mathrm{SO}_{2}$, and $\mathrm{PM}_{10}$ in Pontianak on ARI incidence can be seen in Table 2.

Table 1.

The correlation analysis between air quality parameters with the ARI incidence in Pontianak.

\begin{tabular}{|c|c|c|}
\hline & p-value & Correlation Analysis \\
\hline $\mathbf{N O}_{2}$ & 0,0077 & 0,3275 \\
\hline $\mathbf{C O}$ & 0,0020 & 0,3756 \\
\hline $\mathbf{O}_{\mathbf{3}}$ & 0,0009 & 0,4007 \\
\hline $\mathbf{S O}_{2}$ & 0,0004 & 0,4264 \\
\hline PM$_{10}$ & 0,0166 & 0,2961 \\
\hline
\end{tabular}

The extent of the contribution of air quality to ARI incidence in Pontianak is known through its coefficient of determination (adjusted $\mathrm{R}^{2}$ ) as shown in Table 2, which is 0.4671 . This means that the incidence can be explained by the air quality variables with an effect size of $46.71 \%$. The remaining is contributed by other factors or variables not discussed in this study.

Determination of the influence of each variable can be seen from the $p$ value. If the $p$ value < level of significance $(\alpha=0.05)$, there is a significant influence of these variables. So it can be seen that $\mathrm{NO}_{2}, \mathrm{CO}$, and $\mathrm{SO}_{2}$ influence the ARI incidence in Pontianak. 
Table 2.

Estimation results of multiple linear regression models.

\begin{tabular}{|c|c|c|c|}
\hline & Coefficient & t value & p value \\
\hline Intercept & $-479,274$ & $-0,840$ & 0,4042 \\
\hline $\mathrm{NO}_{2}$ & 130,505 & 2,973 & $0,0043^{*} *$ \\
\hline $\mathrm{CO}$ & 2172,618 & 3,228 & $0,0020^{* *}$ \\
\hline $\mathrm{O}_{3}$ & 5,881 & 0,563 & 0,5754 \\
\hline $\mathrm{SO}_{2}$ & 72,937 & 4,882 & $1,04 \times 10^{-5 * * *}$ \\
\hline $\mathrm{PM}_{10}$ & $-3,952$ & $-0,982$ & 0,3303 \\
\hline \multicolumn{4}{|c|}{$\mathrm{R}^{2}=0,4671$} \\
\hline \multicolumn{4}{|c|}{$F$-statistik $=10,34$} \\
\hline \multicolumn{4}{|c|}{$p$-value $=3,73 \times 10^{-7}$} \\
\hline
\end{tabular}

Li et al. (2018) found that the increasing number of ARI among children aged 0-14 years in Heifei was the effect of short-term exposure to air pollution, especially $\mathrm{NO}_{2}$ as the main air pollutant that affected. This caused an increase the number of hospital visits due to ARI. Humans can produce $\mathrm{NO}_{2}$ into the air from the use of vehicles and burning charcoal, natural gas, and so on. Hrp's research (2018) also found a relationship between $\mathrm{NO}_{2}$ and the ARI incidence. $\mathrm{NO}_{2}$ is four times more toxic than $\mathrm{NO}$ gas. The lungs are particularly sensitive to $\mathrm{NO}_{2}$ gas pollution. Lungs contaminated with $\mathrm{NO}_{2}$ gas swell so that the patient has difficulty in breathing, which can lead to death. $\mathrm{NO}_{2}$ gas first affects the mucous membranes, causing the respiratory tract to swell and stimulating cell growth so that the respiratory tract becomes narrowed, triggering the release of cilia and mucous cell layers. This situation prevents microorganisms that enter from being removed from the respiratory tract, which becomes susceptible to infection.

$\mathrm{SO}_{2}$ in the air is produced by forest fires and transportation fuels. $\mathrm{SO}_{2}$ remains in the air with a slight concentration of water vapor, but if there is enough water vapor in the air, then a reaction occurs with $\mathrm{SO}_{3}$ to form $\mathrm{H}_{2} \mathrm{SO}_{4}$, which affects the mucous membranes of the nose, throat, respiratory tract, and eventually lungs. The primary effect of SOx pollutants on humans is irritation of the respiratory system. $\mathrm{SO}_{2}$ pollutants are considered harmful to health, especially for older adults and people with chronic respiratory conditions (HRP, 2018).

According to Irawan et al. (2017), a relationship exists between CO exposure and hospital visits due to respiratory problems, with a risk of 1.10 and 1.15 after three days of $\mathrm{CO}$ exposure at a concentration of $200 \mathrm{ppb}$. However, several other studies have suggested that $\mathrm{CO}$ concentration is not related to the incidence of ARI. This is possible because the main effect of $\mathrm{CO}$ pollutants on health is shifting $\mathrm{Hb}$ to $\mathrm{COHb}$. According to PDPI (2019), inhalation of $\mathrm{CO}$ has the potential to increase $\mathrm{COHb}$ in the blood and can cause headaches, shortness of breath, nausea, and other symptoms. This allows infection through reduced immunity.

This present study found no correlation between $\mathrm{O}_{3}$ or $\mathrm{PM}_{10}$ concentrations and the ARI incidence in Pontianak City. Most researchers conclude that these two pollutants affect ARI incidence. $\mathrm{O}_{3}$ is a very strong oxidant that can be irritant to the respiratory tract and has lower solubility than $\mathrm{SO}_{2}$ and $\mathrm{NO}_{2}$. Therefore, almost all $\mathrm{O}_{3}$ can penetrate the alveoli, causing symptoms of cough, dry throat, and discomfort in the eyes, chest pain, and headaches. $\mathrm{PM}_{10}$ is mostly produced by forest or land burning, transportation activities, and wind-borne dust. $\mathrm{PM}_{10}$ in the air that enters the body can be detrimental to the respiratory system. In general, its particulate size of about 5 microns means it can directly enter the lungs and settle in the alveoli. Inhalation of 10 -micron matter of $\mathrm{PM}_{10}$ can cause irritation of the upper respiratory tract (HRP, 2018).

The non-existent relationship between $\mathrm{O}_{3}$ or $\mathrm{PM}_{10}$ and the ARI incidence in Pontianak City is possibly due to the lack of specific data analyzed. This is because this study used monthly data, where the concentration value was the average for each one-month period. This data condition definitely affected the outcomes, which are still lacking possible specifics. In addition, not all variables that affect ARI are discussed in this study, even though these other variables may be relevant to Pontianak City. 


\subsection{Effect of the Season on ARI Incidence in Pontianak City}

The estimation results of correlation analysis and multiple linear regression models regarding the impact of air quality of $\mathrm{NO}_{2}\left(\mu \mathrm{g} / \mathrm{m}^{3}\right), \mathrm{CO}\left(\mu \mathrm{g} / \mathrm{m}^{3}\right), \mathrm{O}_{3}\left(\mu \mathrm{g} / \mathrm{m}^{3}\right), \mathrm{SO}_{2}\left(\mu \mathrm{g} / \mathrm{m}^{3}\right)$, and $\mathrm{PM}_{10}\left(\mu \mathrm{g} / \mathrm{m}^{3}\right)$ in Pontianak on ARI incidence can be seen in Table 3 and Table 4.

Correlation analysis the effect of season.

Table 3.

\begin{tabular}{|c|c|c|c|c|}
\hline & \multicolumn{2}{|c|}{ Rainy Season } & \multicolumn{2}{c|}{ Dry Season } \\
\hline & p-value & Correlation Analysis & p-value & Correlation Analysis \\
\hline $\mathrm{NO}_{2}$ & 0,0015 & 0,5894 & 0,0999 & 0,2673 \\
\hline $\mathrm{CO}$ & 0,0441 & 0,3979 & 0,0039 & 0,4515 \\
\hline $\mathrm{O}_{3}$ & 0,0055 & 0,5291 & 0,0614 & 0,3023 \\
\hline $\mathrm{SO}_{2}$ & 0,0018 & 0,5815 & 0,0644 & 0,2991 \\
\hline $\mathrm{PM}_{10}$ & 0,0730 & 0,3574 & 0,0455 & 0,3222 \\
\hline
\end{tabular}

Table 4.

Estimation results of multiple linear regression models based on the effect of season.

\begin{tabular}{|c|c|c|c|c|c|c|c|}
\hline \multicolumn{7}{|c|}{ Rainy Season } & \multicolumn{3}{c|}{ Dry Season } & \\
\hline & Coefficient & $\mathbf{t}$ value & p value & Coefficient & t value & palue & \\
\hline Intercept & $-1161,409$ & $-1,674$ & 0,1106 & Intercept & 7212,794 & 1,729 & 0,0926 \\
\hline NO2 & 215,886 & 3,103 & $0,0059^{* *}$ & CO & 2014,311 & 2,371 & $0,0234^{*}$ \\
\hline CO & 1504,961 & 1,512 & 0,1471 & PM10 & 7,293 & 1,294 & 0,2040 \\
\hline O3 & $-9,563$ & $-0,635$ & 0,5328 & & & & \\
\hline SO2 & 72,288 & 3,697 & $0,0015^{* *}$ & & & & \\
\hline PM10 & $-1,526$ & $-0,308$ & 0,7616 & & & & \\
\hline \multicolumn{6}{|c|}{ R2 $=0,6576$} & & \multicolumn{5}{c|}{ F-statistic $=4,714$} \\
\hline \multicolumn{3}{|c|}{ F-statistic $=9,003$} & p-value $=0,0072$ \\
\hline
\end{tabular}

The extent of the contribution of air quality effect to ARI incidence in Pontianak is known through its coefficient of determination (adjusted $\mathrm{R}^{2}$ ) in Table 4, which was 0.6576 in the rainy season and 0.2267 in the dry season. This means that the ARI incidence in Pontianak City can be explained by air quality with an effect size of $65,76 \%$ in the rainy season and $22,67 \%$ in the dry season. The rest is explained by other factors or variables not discussed in this study. This means that air quality is more affected on the ARI incidence during the rainy season than during the dry season. During rainy season, air quality has a dominant effect on ARI incidence Pontianak City. Meanwhile, during the dry season, the influence of other variables not examined in this study is more affected.

As noted by Ernyasih et al. (2018), rainfall can increase the incidence of ARI, because an area becomes cold and humid. The effect of this rainy season is residential density, which affects crossinfection where coughing and sneezing accelerate ARI transmission. Gagarani (2015) stated that the epidemic of ARI, which is often called a seasonal disease, takes place in the fall and winter: around October to March. In a tropical country such as Indonesia, it can take place throughout the year, with a peak in the rainy season. This happens because of the etiology of ARI, such as bacteria or viruses that prefer low humidity and temperature. The incidence of ARI also increases during the change of seasons. This is due to the decrease in body defenses due to changing weather.

\subsection{Government Policy in Tackling the Incidence of ARI Disease}

Based on the analysis, it was found that the air quality parameters that effected ARI incidence in Pontianak City are $\mathrm{NO}_{2}, \mathrm{CO}$, and $\mathrm{SO}_{2}$ which these parameters are sourced from the transportation, forest and land fires, and burning waste. 
Brugha and Grigg (2014) said that the actions to prevent traffic congestion and reducing emissions (such as zero-emissions vehicles) were an appropriate effort to improve the air quality. The introduction of cleaner indoor fuels and more efficient cook stoves around the world showed promise in reducing deaths from ARI incidence.

Many actions have been taken by the Pontianak City government in tackling forest fires. In terms of prevention, signs forbidding forest fires have been installed (Fig.7) in accordance with Law No. 32 of 2009, as well as evacuation route signs (Fig. 8) and sign of areas of forest and land fires (Fig. 9). The government has also issued a number of policies to increase awareness of haze. Several oxygen houses have been provided in various locations as facilities for use by the community during haze.

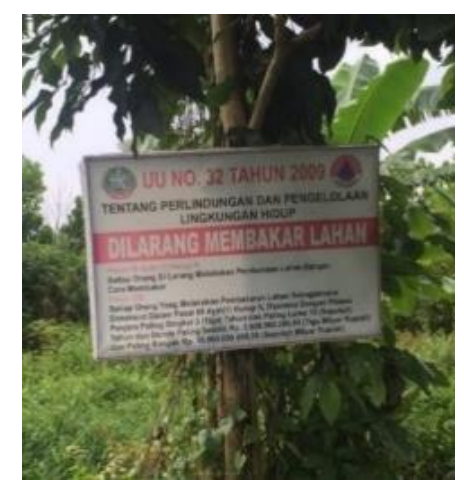

Fig. 7. Signs forbidding forest fires.
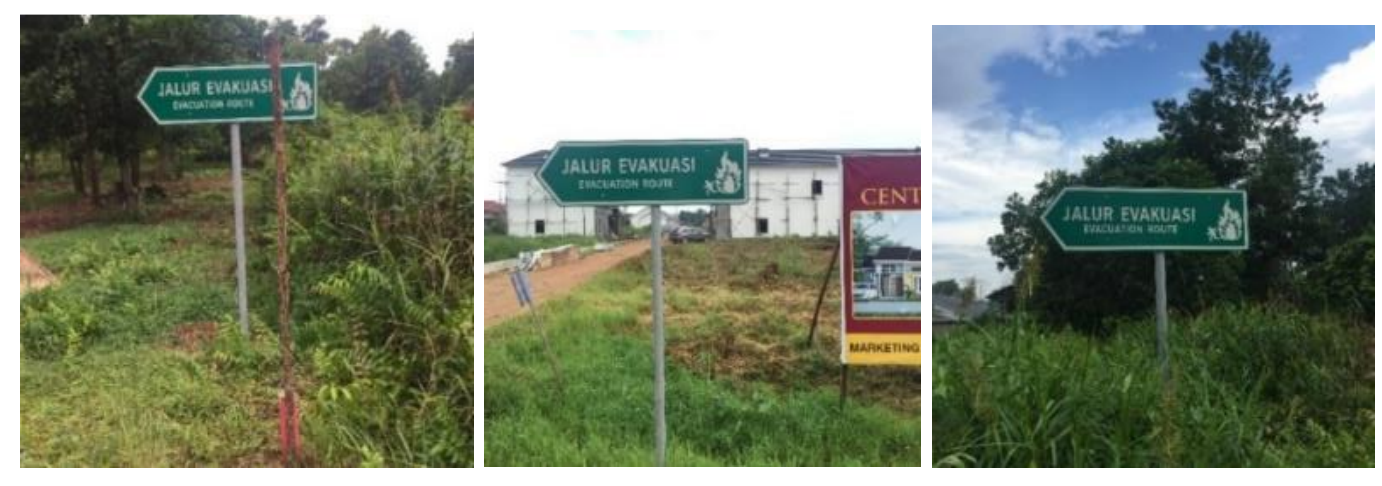

Fig. 8. Evacuation route signs.

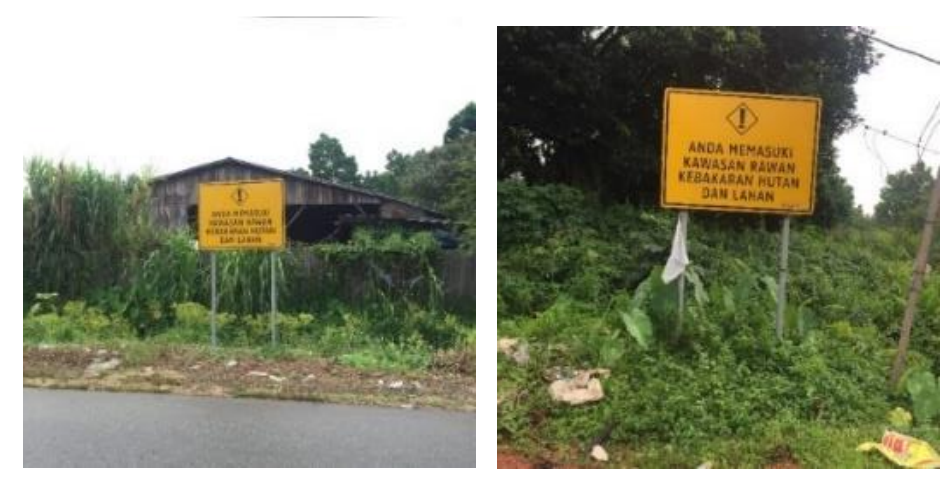

Fig. 9. Sign of areas of forest and land fires. 
Poor air quality is also caused by the transportation sector and burning waste. Therefore, it is necessary to affirm the rules regarding mandatory motor vehicle emissions testing as well as the prohibition of waste burning activities. The next government step that needs to be prepared is to add air quality monitoring stations. The limited air quality monitoring, with only one unit in Pontianak City, causes a lack of information on overall air quality. It is feared that this will not be able to provide a representative picture of air quality in Pontianak City. Additional monitoring stations are expected to be installed and accompanied by proper maintenance efforts. Furthermore, air quality monitoring stations are expected to provide an early warning if poor air quality is identified, to reduce the incidence of ARI.

\section{CONCLUSIONS}

Air quality in Pontianak City has an effect on ARI incidence. The effect size is $46.71 \%$, with the remainder possibly caused by other variables as assessed in this study. Influential pollutants are $\mathrm{NO}_{2}$, $\mathrm{SO}_{2}$, and $\mathrm{CO}$, which sourced from the transportation, forest and land fires, and burning waste and can cause infections in the human respiratory tract. The absence of a relationship between $\mathrm{O}_{3}$ or $\mathrm{PM}_{10}$ and ARI incidence in Pontianak may be due to the lack of specificity of the data analyzed. Besides that, air quality effected ARI incidence with an effect size of $65.76 \%$ in the rainy season and $22.67 \%$ in the dry season. The rest is explained by other factors or variables not discussed in this study. This means that air quality is more affected on the ARI incidence during the rainy season than during the dry season. During rainy season, air quality has a dominant effect on ARI incidence Pontianak City. Meanwhile, during the dry season, the influence of other variables not examined in this study is more affected. So to reduce the incidence of ARI in Pontianak, the action that we can take is by improving the air quality. Many actions have been taken by the Pontianak City government, but it is necessary to affirm the rules so the air quality in Pontianak so it can be prevent the occurrence of poor air quality in Pontianak. Besides that, additional monitoring stations are expected to be installed and accompanied by proper maintenance efforts because only one air quality and monitoring station unit in Pontianak and it can causes a lack of information on overall air quality. Furthermore, air quality monitoring stations are expected to provide an early warning if poor air quality is identified, to reduce the incidence of ARI.

\section{R E F E R E N C E S}

Anggraeni, S. N. (2017) relationship of air quality in home with complaints symptoms of acute respiratory infection in children less than five in marunda flats in north. Thesis, Universitas Islam Negeri Syarif Hidayatullah, Jakarta.

Aprianto, Y., Nurhasanah. \& Sanubary, I. (2018) Particulate Matter (PM10) Prediction for Air Quality Monitoring Using Artificial Neural System with Case Study in Pontianak City. Positron, 8 (1), 15-20.

Adriyani, S. (2012) The relationship between climate factors and chikungunya disease in West Java region in 2002-2010. Thesis, Universitas Indonesia, Depok.

BPS Kota Pontianak. (2018) Pontianak City in Figures 2018. Pontianak Central Statistics Agency, Pontianak.

BPS Kota Pontianak. (2019) Pontianak City in Figures 2019. Pontianak Central Statistics Agency, Pontianak.

BPS Kota Pontianak. (2018) Pontianak City Health Statistics 2017. Pontianak Central Statistics Agency, Pontianak.

Brugha, R. \& Grigg, J. (2014) Urban air pollution and respiratory infections. Paediatric Respiratory Reviews. 15(2), 194-199. doi: 10.1016/j.prrv.2014.03.001

Dinas Kesehatan Kota Pontianak. (2018) Pontianak city health profile in 2017. Pontianak City Health Office, Pontianak. 
Dinayah, K. C. (2014) Air quality, lung function, and respiratory complaints of housewives in affected and unaffected areas of the lapindo mudflow. Jurnal Kesehatan Lingkungan, 7 (2), 90-97.

Gagarani, Y. (2015) Relationship between mother's knowledge level and early management of acute respiratory infection in . Thesis, Universitas Diponegoro, Semarang.

Haidu, I. - editor (2009) Extremes climatiques: genese, modelisation et impacts. Geographia Technica, 4, Special Issue. 493 pp.

Harahap, M. A. (2018) Relationship between ambient air quality $\left(\mathrm{O}_{3}, \mathrm{SO}_{2}, \mathrm{NO}_{2}\right.$ and $\left.\mathrm{PM}_{10}\right)$ and the incidence of ARI (acute respiratory infection) in Pekanbaru City in 2014. Thesis, Universitas Sumatera Utara, Medan.

Indonesian Ministry of Health. (2018) RISKESDAS 2018. Health Research and Development Agency, Jakarta.

Irawan, A., Sutomo, A. H. \& Sukandarrumidi. (2017) Air pollution standards index, meteorological factors, and ARI Occurrence in Pekanbaru. Journal of Community Medicine and Public Health (Berita Kedokteran Masyarakat), 33 (1), 15-32.

Kutner, M. H., Nachtsheim, C. J. \& Neter, J. (2004) Applied Linear Regression Models 4th Ed, Mc. Graw-Hill Companies Inc, New York.

Li, Y. R., Xiao, C. C., Li, J., Tang, J., Geng, X. Y., Cui, L. J. \& Zhai, J. X. (2018) Association between air pollution and upper respiratory tract infection in hospital outpatients Aged 0-14 years in Hefei, China: a time series study. Public Health, 156 (92), 92-100.

Hysenaj, M. (2019) Dispersion model prospective of air pollution in Tirana. Geographia Technica, 14 (2), 10 19.

PDPI (2019) Prevention and Management of Health Impacts from Forest Fire Smoke. Universitas Indonesia, Depok. 